\title{
FIELD EVALUATION OF SOME NON-CONVENTIONAL PESTICIDES ON FABA BEAN LEAF MINER AND ASSOCIATED PARASITOIDS
}

\author{
YACOUB, SH. S. ${ }^{2}$, RASHA A. ELHOSARY ${ }^{1}$ and H. A. A. ABUL FADL ${ }^{2}$ \\ 1- Faculty of Agriculture, Benha University. \\ 2-Plant protection Research Institute, ARC, Dokki, Giza.
}

(Manuscript received $2^{\text {nd }}$ December 2014)

\begin{abstract}
A field experiment was conducted to evaluate the efficiency of some non-conventional pesticides against the leaf miner, Liriomyza trifolii (Burgess) and its parasitoids on faba bean plants from November 2013 to March 2014. There were seven treatments viz, Beauvaria bassiana (biopower), diathaneM45, mineral oils (KZ and Kappi), (ethanol and ethyl acetate extracts of casuarina leaves) and untreated control.. The results showed that, amongest the pesticides tested, Biopower $1.15 \%$ wp significantly reduced larvae population of leafminer by 83.54 and $79.48 \%$ mean percent mortality after the first spray and the second spray, respectively. Followed by ethanol extract of casuarina (63.51 and $60.49 \%)$. The rest of the treatments viz diathane M-45 (64.62 and 18.30), KZ oil (26.9 and 7.48\%), also effective in minimizing the pest population after the first and the second spray application, respectively. Parasitoid species reared from larvae of L.trifoli werei, Diglyphus isaea (Walk.), D.crassinveris (Erdos.), Chrysocharis sp., Neochrysocharis sp. and Hemiptarsenus sp. (Hymenoptera: Eulophidae). Significantly higher seed yields were recorded from biopower, Diathane and ethanol casuarina leaves extract plots as compared to yields from KZ oil, ethyl acetate extract, kappi oil and untreated control .
\end{abstract}

Key words: L. trifolii, mineral oils, casuarina extract, parasitoids, Faba bean.

\section{INTRODUCTION}

Faba bean, Vicia faba L. is considered the most important legume crop due to its high nutritive value it is primary source of protein for grown from seed in Egypt for the majority of people. Faba bean plants are attacked by several insect pests.

The leaf miners, Liriomyza spp. [Diptera: Agromyzidae] are among the most damaging insects of the many insects associated with field crops, the serious pests on field crops, vegetables and ornamental plants all over the world. The faba bean leaf miner, L. trifolii is basically an invasive pest to Egypt's agro-climate and recorded as a harmful and wide spread on faba bean (El-Hemaesy, et al. 1974, Aly and Makady, 1990). It is indigenous to the new world, but has extended its geographical range to Asia, Africa and Europe (Saito, 1997). 
L. trifolii larvae cause direct injury for the leaves as tunneling into the soft plant tissue causing, the characteristic serpentine "leaf mines" which are externally visible as whitish grey trick up of variable shape as result of feeding on the mesophyll tissues between the epidermal layers of leaves and subsequently reduce photosynthesis potential (Ledieu and Helyer, 1985).

The different biocides control against the leaf miners Liriomyza spp., significantly, reduced the number of larvae such as the fungicide, diathane-M45 on faba bean (Ibrahim and Abd-El-Moiety 1997),. Likewise, the toxicity of Casuarina equisetifolia leaf extracts against the spiny bollworm Earias insulana (Boisd.) caused the highest reduction percentage (57.14\%) in larval infestation (Zaki, 2012). In the same direction, the use of summer mineral oil (KZ 1\%) against the citrus leaf miner, Phyllocnists citrella achieved the highest percentage reduction by the recommended rate.

Hymenopterous parasitoids reared from L. trifolii were, Opius sp. (Braconidae) El-Serwy (1993), Chrysonotomyia sp. (Eulophidae) also, Halticoptera $s p$. (Pteromalidae) Metwally (1991),El-Serwy (1993) and Shahin and El-Maghraby (1993) Extensive studies have been continuously encouraged and developed in the field of biological control of insect pests using many bio-control agents. Recent control strategies depend principally on knowing pest natural enemies relationship.

Use of insecticide is found one of the most effective ways to control leaf miner (Gerling 1986). But due to injudicious application, leaf miner had already acquired resistance to insecticides moreover, extensive chemical control often caused population resurgence due to a negative impact on natural enemies (Parrella and Jones, 1987).

The present work aimed to evaluate and throw light on the impact of the nonconventional pesticides against $L$. triofolii, and also their positive or negative efficiency on associated on $L$. trifolii parasitoids, in addition to determine the economic efficiency on the resultant yield.

\section{MATERIALS AND METHODS}

\section{I- Field preparation and foliar spray experiments:}

The present experiment was carried out throughout growing season of faba bean 2013/2014 at Experimental farm Research Station of Faculty of Agriculture at Moshtohor, Benha University. An area of about $1 / 4$ feddan $\left(4200 \mathrm{~m}^{2}\right)$ was sown with common commercial variety seeds of faba bean, Giza 3 on November, $11^{\text {th }} 2013$. The area was divided into 28 plots, each of $2.5 \mathrm{~m} \times 3 \mathrm{~m}$. The experimental plots were 
arranged in complete randomized block design. Four replicates per treatment, four lines for each. All agricultural practices were followed without using any chemicals. Each of the following treatments and extracts were applied:

1. Biopower (1.15\% WP), Beauvaria bassiana entomopathogenic fungus. $\left(1 \times 10^{8} \mathrm{CFU} / \mathrm{gm}\right)$.

2. KZ oil-mineral oil ( $95 \%$ E.C.).

3. Kappi oil-mineral oil ( $96.5 \%$ E.C.).

4. Dithane M45:Fungicide (Manganes ethylene bis) dithiocarbamate Polymeric complex with zinc salt

5. Extract of dried Casuarina leaves in ethanol $95 \%$.

6. Extract of dried Casuarina leaves in ethyl acetate.

7. Untreated control .

Applications of the assayed materials took place by using five liters hand sprayer. The pesticides application were done twice on 25 November and on 25 December. There was non-treated buffer zone of $1 \mathrm{~m}$ between each plots to prevent spay drift to adjacent plots. Faba bean plants were examined after two weeks from sowing then weekly until harvesting date. 25 leaflets for each replicate were randomly picked before spraying and after 7, 14 and 21 days from each application and transferred to the laboratory in paper bags for inspection by the aid of stereomicroscope and live larval counts were recorded.

\section{Preparation of crude extracts:}

Extractions were prepared as described by Afifi, et al. (1988). Fully grown green leaves of Casuarina equisetifolia were washed thoroughly by water and air dried in shade under laboratory conditions. The tested parts were ground in a high speed grinder. Every 50 gram of leaves powder was weighed, then put in ( $250 \mathrm{ml}$ glass jar), to be extracted by different organic solvents (Ethyl alcohol 95\% and ethyl acetate)The solvent was added at rate of 1 (gm powder): 2 ( $\mathrm{cm}^{3}$ solvent). Jars were tightly closed to prevent solvent evaporation ,then kept for 7 days in freezer, at $-4 \pm 1^{\circ} \mathrm{C}$. The glass jars were shacked for $10 \mathrm{~min}$. before being filtered. Filtration took place through funnel containing a piece of muslin cloth. The Petri-dishes used for receiving the plant extract were weighed, then left until dryness, then peti-dishes were weighed. The crude extract was, then, prepared at concentration $8000 \mu \mathrm{g} / \mathrm{ml}$ for both solvents. The crude extract was kept in refrigerator at $4{ }^{\circ} \mathrm{C}$ until time of application in the field.

\section{III - Parasitoids on L. trifolii larvae:}

To evaluate the effect of the previous treatments on the different parasitoids throughout experimental season, large number of $L$. trifolii larvae were collected from faba bean plants leaflets. The collected faba bean leaves per treatment were kept in 
the laboratory in small glass containers $\left(3 \times 7 \mathrm{~cm}^{2}\right)$ at $25 \pm 2{ }^{\circ} \mathrm{C}$ and $60 \pm 5 \% \mathrm{RH}$. Emerged parasitoids were kept in $70 \%$ alcohol and glycerin placed in glass vials. They were daily checked for the emerging leaf miners and their parasitoids. Its identified in the identification unit, Biological Control Research Department, Plant Protection Research Institute, ARC. The relationship between the tested treatments and the population density of parasitoids were recorded.

\section{IV- Effect of assayed pesticides on values of yield:}

At harvest time, 100 plants from each treatment were picked and the numbers of pods were

counted per plant, then 100 seed were weighed from each treatment. The obtained yield/ treatment was adjusted to find out the yield of seeds/ feddan.

\section{V-Statistical analysis:}

To evaluate the efficiency of tested pesticides and extracts against $L$. trifolii, the percentage of population density reduction was calculated according the formula given by Henderson and Tiliton (1955) as follow: Reduction $\%=100[1-(\mathrm{Ta} \times \mathrm{Cb}) /(\mathrm{Tb} \times \mathrm{Ca})]$ Where: $\mathrm{Tb}=$ pre-treatment count, $\mathrm{Ta}=$ Post-treatment count, $\mathrm{Cb}=$ count in the control before treatment and $\mathrm{Ca}=$ count in the control after treatment.

Percentages of parasitism by parasitoids species associated with $L$. trifolii on faba bean plants were determined with their reduction percentages. Reduction percentages of parasitism were calculated as: $\%$ Reduction in parasitism $=[$ (No. of parasitized larvae in treatment $/$ No. of parasitized larva in control) $\times 100]-100$

Also, the data of yield/ treatment obtained was statistically evaluated by analysis of variance (ANOVA) and the treatment were compared by least significant difference (L.S.D.) at 5\% level.

\section{RESULTS AND DISCUSSION}

\section{1-Effectiveness of assayed formulations and plant extracts against $\boldsymbol{L}$. trifolit larvae infesting faba bean plants in the field.}

\section{1-First spray:}

Data in Table (1) show the mean numbers and \% reduction of the leaf miner L. trifolii larvae infesting faba bean plants during three weeks after application of seven treatments,. Biopower treatment achieved the highest efficacy and significantly to reduce the numbers of $L$. trifalii larvae by $71.01,91.51$ and $88.10 \%$ reduction after the first, second and third week, respectively being (83.54\%) as mean reductions. This was followed by dithane M-45, Casuarina leaves extract in ethanol being (64.62 and63.51) as mean reduction. Mineral oils (KZ and Kappi) treatments had moderate 
effects. (Table 1). KZ oil treatment gave the lowest effect on $L$. trifolii larval population (after second and third weeks of application). It gave 22.24 and $16.47 \%$ reduction after the second and third week of applications. While, kappi oil treatment caused 34.12 and $29.62 \%$ reductions during the same intervals, respectively.

Casuarina leaves extract in ethyl acetate had no detrimental effect against $L$. trifolii population. It gave lower than $50 \%$ reduction in leaf miner population (after first week of application). However, under conditions of the experiment biopower, dithane $M-45$. Casuarina leaves extract in ethanol and Casuarina leaves extract in ethyl acetate considered effective for reducing leaf miner population (after second and third week of application) offering more than $50 \%$ reduction

Table 1. Effect non-conventional pesticides on the number of $L$. trifolii larvae in faba bean fields

\begin{tabular}{|c|c|c|c|c|c|c|c|c|}
\hline \multirow[b]{2}{*}{ Treatments } & \multicolumn{8}{|c|}{$1^{\text {st }}$ Spray } \\
\hline & $\begin{array}{l}\text { mean No. } \\
\text { before } \\
\text { treatment }\end{array}$ & $\begin{array}{c}\text { After } \\
\text { 1week }\end{array}$ & $\begin{array}{c}\text { Reduction } \\
\%\end{array}$ & $\begin{array}{c}\text { After } \\
\text { 2week }\end{array}$ & $\begin{array}{c}\text { Reduction } \\
\quad \%\end{array}$ & $\begin{array}{c}\text { After } \\
3 \text { week }\end{array}$ & $\begin{array}{c}\text { Reduction } \\
\%\end{array}$ & $\begin{array}{c}\text { Mean } \\
\text { Reduction } \\
\%\end{array}$ \\
\hline $\begin{array}{l}\text { Casuarina } \\
\text { ext. } \\
\text { in ethanol }\end{array}$ & 90 & 45.83 & 57.93 & 31.25 & 68.06 & 35.25 & 64.53 & 63.51 \\
\hline KZ-oil & 65.38 & 45.9 & 42.00 & 55.26 & 22.24 & 60.3 & 16.47 & 26.90 \\
\hline $\begin{array}{c}\text { Casuarina } \\
\text { ext. } \\
\text { in ethyl } \\
\text { acetate }\end{array}$ & 70.69 & 66.6 & 22.17 & 33.69 & 56.15 & 30 & 61.56 & 46.63 \\
\hline Biopower & 127.94 & 44.9 & 71.01 & 11.81 & 91.51 & 16.81 & 88.10 & 83.54 \\
\hline Kappi oil & 65.47 & 45.8 & 42.21 & 46.88 & 34.12 & 50.88 & 29.62 & 35.32 \\
\hline $\begin{array}{c}\text { Diathane } \\
\text { M-45 }\end{array}$ & 75 & 55.8 & 38.54 & 17.86 & 78.09 & 18.86 & 77.23 & 64.62 \\
\hline Control & 101.2 & 122.5 & & 110 & & 111.74 & & \\
\hline
\end{tabular}

The tested materials could be arranged descendingly according to their effect on leaf miner L.trifolii larvae population as: biopower - dithane M-45. Casuarina leaves extract in ethanol - Casuarina leaves extract in ethyl acetate - Kappi oil · KZ oil

\section{2-Second spray}

Regarding data in Table (2) Biopower and Casuarina leaves extract in ethanol treatments gave the highest efficacy on $L$. trifotii larval population. Biopower gave $80.32,75.76$ and $82.36 \%$ reductions after the first, second and third weeks of application ,respectively. While, Casuarina leaves extract in ethanol treatment ranked the second, with percentage reduction $55.19,58.00$ and $68.27 \%$ reduction during the 
same weeks, respectively (Table, 2). In this respect, the present results are in accordance with that of Jacob et al., (2007) who studied the influence of casuarina leaf extract on growth, yield and insect pests in vegetables. The Recommendation that spraying with casuarina reduced fruit borer infestation. In the same side,

Zaki (2012) found that leaf extract caused reduction percentage of 57.14 and $42.25 \%$ in larval infestation of the pink bollworm after one and two weeks from sprays, respectively. Also, it caused reduction in the number of Jassids and white fly after 3, 7 and 10 days after spray. The same result was obtained by Ibrahim and AbdEl-Moiety (1997) found that spraying of dithane-M45 against leaf miner every two weeks on faba bean plant achieved $60 \%$ reduction than control as general mean for two study seasons 94/95 and 95/96. While, Kappi oil, KZ oil, Casuarina leaves extract in ethyl acetate and dithane M-45 treatments caused lower effect than $50 \%$ reduction of leaf miner larvae after first, second and third week of application, respectively.

The treatments could be arranged descending according to their average of leaf miner as percentage of total reduction as follows: biopower - Casuarina leaves extract in ethanol - dithane M-45 - Casuarina leaves extract in ethyl acetate - KZ oil · Kappi oil.

\section{2-Common parasitoid species attacking L. trifolli :}

Five parasitoid species were collected from larvae and pupae of $L$. trifolii belonging to one order (Hymenoptera) and one family (Eulophidae). The secured parasitoids were (1) Diglyphus isaea (Walk), (2) D. crassinerviun (Erdos.), (3) Chrysocharis sp.,(4) Neochrysocharis sp. and (5) Hemiptarsenus sp. Several authors recorded the mentioned parasitoids from L. trifolii such as, El-Serwy (1993),Shahin and El-Maghraby (1993) and AbulFadl and El-Khawas (2009).

\subsection{Effect of different treatments on parasitism and percentages of parasitism reduction:}

The mean percentages of reduction in parasitism on $L$. trifolii as compared to untreated control were, 10.3, 51.5, 54.4, 58.8,63.2 and 66.8\% by KZ oil , Kappi oil, Casuarina leaves extract in ethanol, Casuarina leaves extract in ethyl acetate , Biopower and dithane $M-45$, respectively (Table 3 ). The mean numbers of parasitized L. trifolii (IS) were, 30.5, 16.5, 15.5,14, 12.5, 11.5 and 34 individuals for KZ oil, Kappi oil, Casuarina leaves extract in ethanol, Casuarina leaves extract in ethyl acetate, Biopower, dithane $M-45$, and untreated controls, respectively.The means of $L$. trifolii percentages of parasitism were, 35.9, 16.3, 14.5, 10.6, 10.3, 9.8 and 10.8\% for KZ oil, Casuarina leaves extract in ethanol, Kappi oil, dithane M-45 , Biopower,Casuarina leaves extract in ethyl acetate and untreated control, respectively (Table 3). Obtained results showed that $\mathrm{KZ}$ oil and Casuarina leaves extract in ethyl acetate had the 
highest and the lowest efficacies on parasitism \%, respectively Also, the obtained data showed that dithane M-45 and KZ oil were correlated with the highest and the lowest percentages reduction of parasitism, respectively (Table 3 ).

Table 2. Effect of non-convential pesticides on the numbers of $L$. trifolii larvae on faba bean plants.

\begin{tabular}{|c|c|c|c|c|c|c|c|c|}
\hline \multirow[b]{2}{*}{ Treatments } & \multicolumn{8}{|c|}{$2^{\text {nd }}$ Spray } \\
\hline & $\begin{array}{l}\text { mean No. } \\
\text { before } \\
\text { treatment }\end{array}$ & $\begin{array}{l}\text { After } \\
\text { 1week }\end{array}$ & $\begin{array}{c}\text { Reduction } \\
\text { \% }\end{array}$ & $\begin{array}{c}\text { After } \\
\text { 2week } \\
\text { s }\end{array}$ & $\begin{array}{c}\text { Reduction } \\
\quad \%\end{array}$ & $\begin{array}{c}\text { After } \\
\text { 3weeks }\end{array}$ & $\begin{array}{c}\text { Reduction } \\
\%\end{array}$ & $\begin{array}{c}\text { Mean } \\
\text { Reduction } \\
\%\end{array}$ \\
\hline $\begin{array}{c}\text { Casuarina ext. } \\
\text { in ethanol }\end{array}$ & 190.38 & 52.08 & 55.19 & 46.86 & 58.00 & 40.7 & 68.27 & 60.49 \\
\hline KZ-oil & 177.27 & 97.22 & 10.17 & 95.18 & 14.69 & 85.8 & 28.15 & 17.67 \\
\hline $\begin{array}{l}\text { Casuarina ext. } \\
\text { in ethyl acetate }\end{array}$ & 171.2 & 87.5 & 16.29 & 87.56 & 12.74 & 85.51 & 25.86 & 18.30 \\
\hline Biopower & 208.03 & 25 & 80.32 & 29.56 & 75.76 & 24.72 & 82.36 & 79.48 \\
\hline Kappi oil & 158.04 & 91.07 & 5.61 & 92.24 & 0.42 & 89 & 16.40 & 7.48 \\
\hline Diathane M-45 & 179.69 & 78.57 & 28.38 & 87.5 & 16.92 & 78 & 35.56 & 26.95 \\
\hline Control & 245.69 & 150 & & 144 & & 165.51 & & \\
\hline
\end{tabular}

\subsection{Effect of assayed formulations and plant extracts on the average yield and number of pods per plant:}

Data in Table (4) show the effect of foliar spray of faba bean plants with the assayed formulations and extracts on the average weight of 100 - seeds, number of pods/ plant and seed yield/ feddan. There were significant differences between the different treatments of bio-insecticides and mineral oils.

All treatments caused increasing in the weight of seed yield, especially those of biopower which achieved the highest yield (112.28 Kg seeds/ feddan, respectively), followed by treatments with dithane M-45 and Casuarina leaves extract in ethanol which showed significant differences than the remaining treatments which achieved 103.04 and $99.12 \mathrm{~kg} /$ feddan, respectively.. Likewise, the highest mean number of pods/ plant were obtained by dithane M-45 .Followed by biopower, KZ oil and Casuarina leaves extract in ethanol, respectively Table (4). 
Table 3. Effect of non-convential pesticides on the number of parasitized $L$. trifolii larvae, \% parasitism and \% reduction of parasitism on faba bean plants .

\begin{tabular}{|c|c|c|c|}
\hline Treatments & $\begin{array}{c}\text { Mean number of } \\
\text { parasitized larvae }\end{array}$ & $\begin{array}{c}\% \\
\text { parasitism }\end{array}$ & $\begin{array}{c}\text { \%reduction } \\
\text { parasitism }\end{array}$ \\
\cline { 2 - 4 } Casuarina ext. in ethanol & 15.5 & 16.3 & 54.4 \\
\hline KZ-oil & 30.5 & 35.9 & 10.3 \\
\hline Casuarina ext. in ethyl acetate & 14 & 9.8 & 58.8 \\
\hline Biopower & 12.5 & 10.3 & 63.2 \\
\hline Kappi oil & 16.5 & 14.5 & 51.5 \\
\hline diathane & 11.5 & 10.6 & 66.8 \\
\hline M-45 & 34 & 10.8 & \\
\hline
\end{tabular}

Table 4. Effect of non-conventional pesticides on the average weights yield .

\begin{tabular}{|c|c|c|c|}
\hline Treatments & $\begin{array}{c}\text { Average weight of } \\
100 \text {-seeds }(\mathrm{gm})\end{array}$ & $\begin{array}{c}\text { Mean No. of } \\
\text { pods/ Plant }\end{array}$ & $\begin{array}{c}\text { Mean seed } \\
\text { yield /fed (Kg) }\end{array}$ \\
\hline $\begin{array}{c}\text { Casuarina ext. } \\
\text { in ethanol }\end{array}$ & $0.08^{\mathrm{a}}$ & $1.67^{\mathrm{ab}}$ & 99.12 \\
\hline KZ-oil & $0.07^{\mathrm{a}}$ & $1.78^{\mathrm{ab}}$ & 78.4 \\
\hline $\begin{array}{c}\text { Casuarina ext. } \\
\text { in ethyl acetate }\end{array}$ & $0.08^{\mathrm{a}}$ & $1.09^{\mathrm{c}}$ & 70 \\
\hline biopower & $0.09^{\mathrm{a}}$ & $1.86^{\mathrm{a}}$ & 112.28 \\
\hline Kappi oil & $0.08^{\mathrm{a}}$ & $1.47^{\mathrm{ab}}$ & 63 \\
\hline dithane M-45 & $0.08^{\mathrm{a}}$ & $2.25^{\mathrm{a}}$ & 103.04 \\
\hline Control & $0.07^{\mathrm{a}}$ & $1.11^{\mathrm{b}}$ & 61.6 \\
\hline L.S.D. $0.05 \%$ & $0.003^{\mathrm{a}}$ & 0.18 & 12.48 \\
\hline
\end{tabular}

These results agree with those of Ibrahim and Abd-El-Moiety (1997) who studied the effects of $L$. trifolii larval damage on yield of celery in Florida. The authors indicated highly significant negative simple correlation between the infested leaflets by the leaf miners and the yield.

\section{REFERENCES}

1. Abul Fadl, H.A. and El-Khawas, M.A. 2009. Incidence of parasitoids on the leaf miner species, Liriomyza trifolii (Burgess) (Diptera: Agromyzidae), in Tomato Fields, at Qalubia Governorate, Egypt. Egypt. J. Biol. Pest control, 19(2): 93-97.

2. Afifi, F.A., Hekal A.M. and Salem M. 1988. Fenugreek seed extract as protestants of wheat grain against certain strored product insects. Ann. of Agric. Sci., Fac. Agric., Ain Shams Univ., Cairo, Egypt, 33 (2): 1331-1344. 
3. Aly, F.K. and Makadey M.A. 1990. Population density of Liriomyza congesta (Beck) in relation to infestation and yield of broad bean, Bull. Soc. Ent. Egypte. 69: 123-128.

4. El-Hemaesy, A.H., Hammad S.M. and Tantawy G. 1974. Control of the leaf miner Liriomyza trifolii (Burgess) on broad bean. Bull. Ent. Soc. Egypt.Econ. Ser., III: 197-205.

5. El-Serwy, S.A. 1993. Preliminary field observation on the infestation, mine density, larval and pupal parasitism of Liriomyza trifolii (Burgess) (Diptera: Agromyzidae). Bull. Ent. Soc. Egypt. (71): 75-81.

6. Gerling, D. 1986. Natural enemies of Liriomyza trifolii, biological characteristics and potential as biological control agents. A review Agriculture. Ecosystems and Environ. 17, 99-110.

7. Henderson, C.F. and Tiliton E.W. 1955. Test with acaricides against the brown wheat mites. J. Econ. Entomol., 48: 157-161.

8. Ibrahim, S.M. and Abd-El-Moiety, S. 1997. Biocontrol of the leaf miners Liriomyza spp. (Diptera: Agromyzidae) and fungal leaf spots by Trichoderma spp. on faba bean. Alex. Sci. Exch., Vol. 18 No.3, pp. 405-416.

9. Jacob, J., Leela, N.K., Sreekumar, K.M., Aneesh, R .Y. and Hema, M. 2007. Phytotoxicity of leaf extracts of multipurpose trees against insect pests in bitter gourd (Momordica charantia) and brinjai (Solanumme longena). Allelopathy J., 20: 411-418.

10. Ledieu, M. S. and Helyer, N. L. 1985. Observations on the economic importance of tomato leaf miner (Liriomyza bryoniae) (Agromyzidae). Agriculture, Ecosystem and Environ. 13: 103-109.

11. Metwally Samia, G. 1991. Population studies on Liriomyza trifolii (Burgess) (Dipetra: Agromyzidae) and its parasitoids in Egypt . Egypt. J. Bio. pest Cont. 1 (1): 23-30.

12. Parrella, M.P. and Jones V.P. 1987. Development of integrated pest management strategies in floriculture. Bulletin of the Entomological society of America, 33: 28-34.

13. Saito,T. 1997. [Liriomyza trifolii] Nosan-gyoson -bunka -Kyokai.Tokyo, 103 pp. (in Japanese).

14. Shahein, A. and El-Maghraby, M.M. 1993. Impact of parasitoids of Liriomyza trifolii (Burgess) on broad beans. Zeitschrift. Fur. Angewandte Zoologie, 79 (1): 37-43.

15. Zaki, A.A. 2012. Evaluation of both leaf and bark extracts of Casuarina equisetifolia against the Pink, Spiny Bollworms and some sucking insects. Egypt. J. Agric. Res., 90 (2): 911-927. 


\section{التقييم الحقلي لبعض المبيدات غير التقليدية علي صانعة انفاق}

أوراق نباتات الفول البلدي وعلي بعض الطفيلات المصاحبة لها

شنوده سيد يعقوب' ، رشا علي الحصري' ، حازم عبد الرعوف ابو الفضل'

$$
\begin{aligned}
& 1 \text { - معهد بحوث وقاية النباتات - مركز البحوث الزراعية - الدقي - الجيزة- مصر } \\
& \text { r - بلبة الزراعة - - جامعة بنها }
\end{aligned}
$$

تم اجر اء تجربة في حقول الفول البلدي لتقييم كفاءة بعض المبيدات غير التقليدية في مكافحة

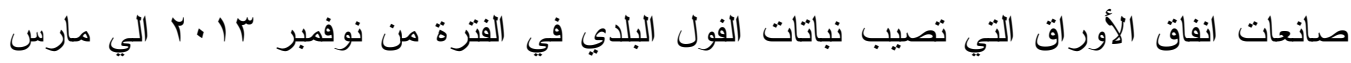
ـ ا.بوذذلك باستخدام المبيد الفطري (دياثين- م 0؛) و الفطر الممرض للحشرات (بايو باور)، و الزيوت المعدنية ( كزد، وكابي) و (مستخلصي اوراق الكازورينا بالايثانول والايثيل أسيتات) وتأثنير اتهم علي أعداد طفيلات اليرقات .و أوضحت النتائج ان المبيد الحيوي بيوباور حقق اعلي ألي نسبة

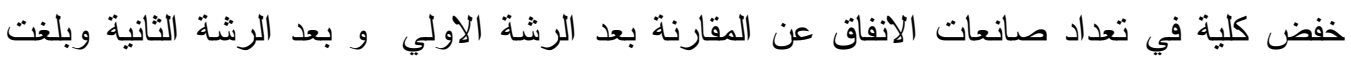

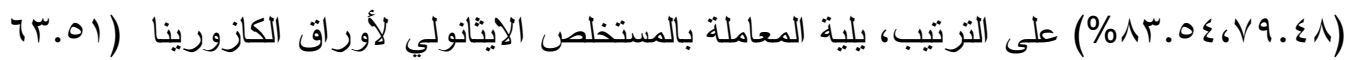

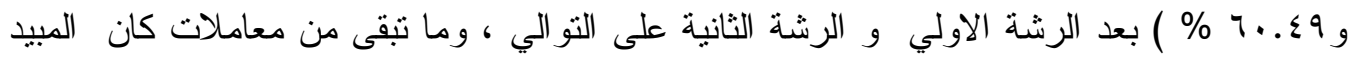

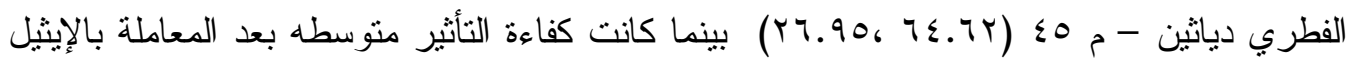

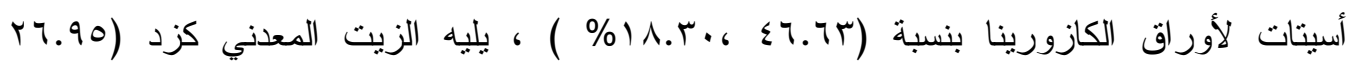

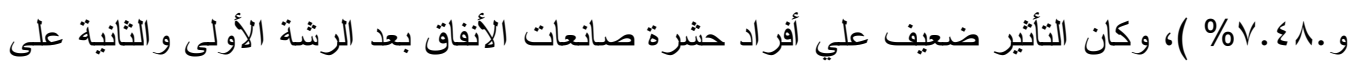

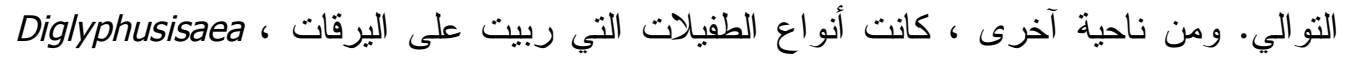
(Walk), D.crassinveris (Wlalk.), Chrysocharis sp., Neochrysocharis sp. and خلال فتزة الدراسة .و اخيرا نم الحصول Hemiptarsenus sp. (Hymenoptera: Eulophidae) على محصول بذور مرتفع معنويا بعد معاملات المبيد بيوباور، الدياثيين-م0ء، و المستخلص

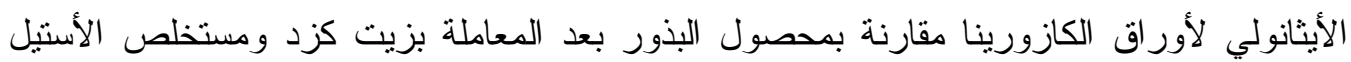

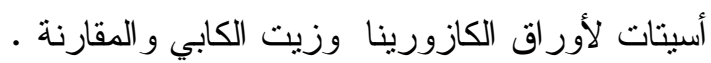

